\title{
Acid-Fast Bacilli Measurement
}

National Cancer Institute

\section{Source}

National Cancer Institute. Acid-Fast Bacilli Measurement. NCI Thesaurus. Code C128981.

The determination of the amount of acid-fast bacilli present in a sample. 